\title{
Characterization of the Landscape Units of the Residual Massif of the Pacoti River Watershed, Ceará, Brazil
}

\author{
Ms. Álvaro Andrade Dourado ${ }^{1,2}$, Prof. Dr. José Falcão Sobrinho ${ }^{2} \&$ Dra. Francisca Edineide Lima Barbosa ${ }^{3}$ \\ ${ }^{1}$ Universidade Estadual Vale do Acaraú (UVA), Ceará, Brasil. Mestre em Geografia (MAG), Brazil \\ ${ }^{2}$ Universidade Estadual Vale do Acaraú, UVA, Ceará, Brasil. Grupo de Pesquisa e Extensão do Semiárido/CNPq, \\ Brazil \\ ${ }^{3}$ Universidade Estadual Vale do Acaraú, UVA, Ceará, Brasil. Pós-doctor em Geografia do MAG/UVA, Brazil \\ Correspondence: Prof. Dr. José Falcão Sobrinho, Universidade Estadual Vale do Acaraú, UVA, Ceará, Brasil. \\ Grupo de Pesquisa e Extensão do Semiárido/CNPq, Brazil. E-mail: falcao.sobral@gmail.com
}

Received: March 16, 2021

doi:10.5539/jsd.v14n3p107
Accepted: April 21, $2021 \quad$ Online Published: April 23, 2021

URL: https://doi.org/10.5539/jsd.v14n3p107

\begin{abstract}
Digital technology helps to visualize the natural potentiality of the landscapes that exist on the earthly surface. Indeed, information is more significant with fieldwork. The interpretation of the images through the application of the image segmentation function, available in the SPRING 5.5.5 software, granted the understanding of natural landscapes in the Pacoti River Watershed, precisely in the Baturité Residual Massif. Thus, geoprocessing may act as a mitigating tool in nature conservation since this tool reveals the diversity in nature and its uses.
\end{abstract}

Keywords: Baturité Residual Massif, geoprocessing, physical geography

\section{Introduction}

Ceará comprises 184 (one hundred and eighty-four) municipalities in its totality, of which 175 (one hundred and seventy-five) are inside the Ceará semi-arid polygon. It is around $95 \%$ (ninety-five) of the state, according to data from the Superitendência do Desenvolvimento do Nordeste (Superintendence for the Development of the Northeast, SUDENE).

Ceará has a significant heterogeneous relief morphology, being most of the state inserted in the pediplain. It also has humid and dry residual massifs - the Baturité Massif - and sedimentary plateaus - the Araripe Plateau. Ceará currently contains 12 watersheds spread over its territory, according to a report by the Ceará Watershed Committee (COGERH, 2016). The watersheds delimitations are political arrangements to manage the state water resources.

Among them, the Metropolitan River Basin of Fortaleza stands out for its importance and different geomorphological compartments. Created on February 1, 2003, by the State Decree 26.902, it has an estimated population of 3.840 .000 people distributed in 38 municipalities spread over $15.100 \mathrm{~km}^{2}$ of territorial area.

The Pacoti River is the largest of the watercourses that cross the metropolitan area of Fortaleza, with its source in the eastern slope in the residual massif called Baturité Mountain, covering about $150 \mathrm{~km}$ to flow into the sea. The analyzed area (Figure 1) shares the same limits as the Pacoti River Watershed, whose source is in the Baturité Massif and crosses the pediplain until the coastal zone in Aquiraz. 


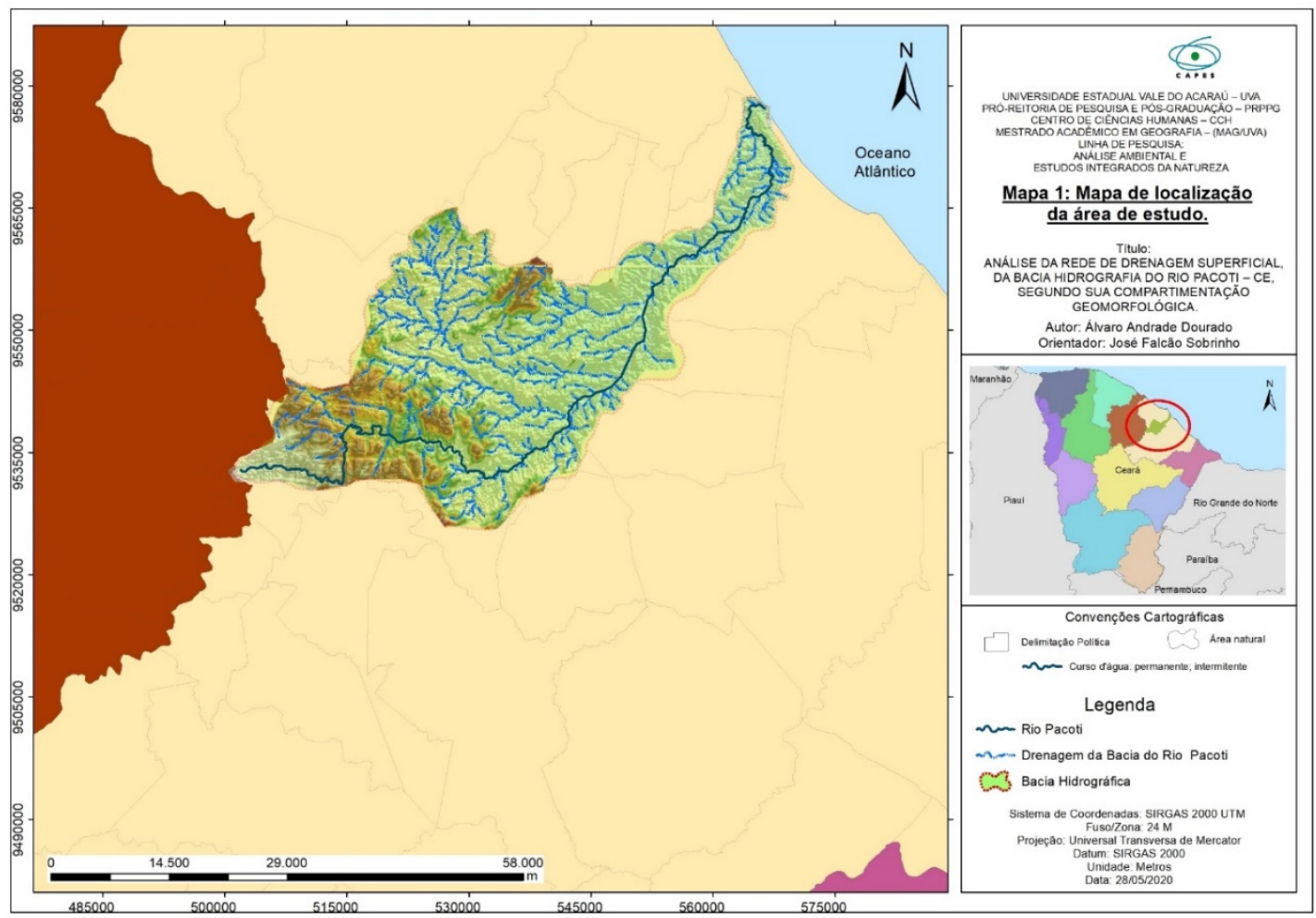

Figure 1. Location map of the analyzed area

Source: made by the authors (2020).

The Pacoti River Watershed (Figure 1) has around 132,717.60 hectares and is a sub-basin of the Great Metropolitan Basin, with about 1.5 million hectares. Therefore, the Pacoti Watershed corresponds to $8.83 \%$ of the area of the Metropolitan Basin.

Based on the context of the different types of landscapes and geomorphologic compartments found along the Pacoti River, from its source to its mouth, and the importance of the water supply of the capital and metropolitan region, the interest in analyzing the natural characteristics of the watershed arose. The object of study in this manuscript is the Residual Massif in the Pacoti River Watershed, popularly known as Baturité Mountains. In this opportunity, there was the production of maps of the natural landscape units.

\subsection{Technical and Methodological-Operational Guidance}

The research has foundations on the General System Theory proposed by the German biologist Ludwig von Bertalanffy in 1930, based on the Pacoti River Watershed. In this perspective, when making a geographic study, it is necessary to use the concept of system to understand the complex issues as they are interdependent, that is, the variable natural units inserted in the study area (Dourado, 2021; Dourado et al, 2021)

Thus, in a systemic approach, watersheds integrate a joint vision of the behavior of natural conditions and human activities developed in them, since significant changes in any of these units can generate changes, effects, and negative or positive impacts. As a rule, it establishes the relief as a possible unit to map more expressively without losing the sense that they are related (Falcão Sobrinho, 2007, 2020). 


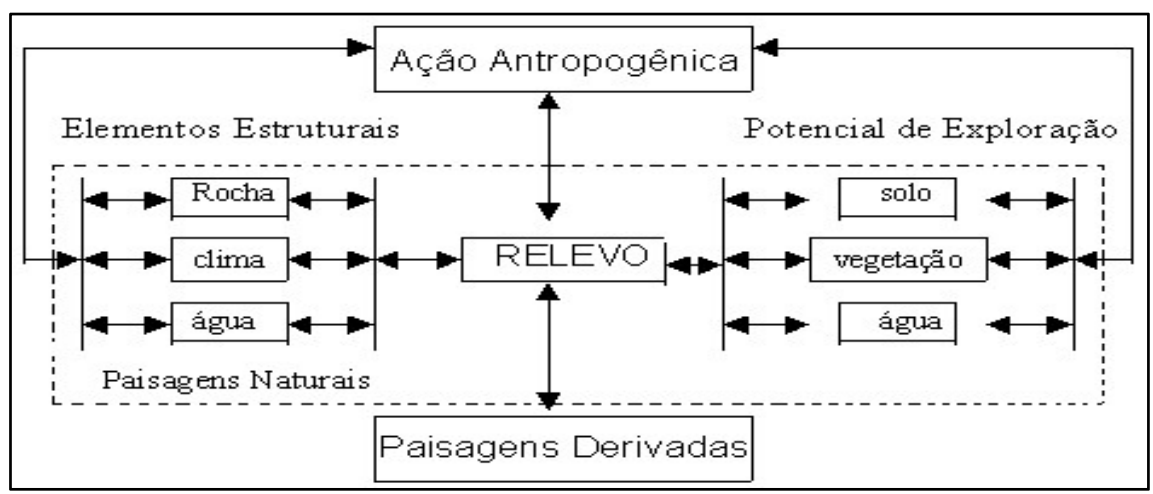

Figure 2. Relief, the stage for joint landscape

Source: FALCÃO SOBRINHO, José $(2007,2020)$.

To the author, the structural elements (rock, climate, and water) that make up the scenario of natural landscapes comprise in this study the exploitation potential constituted by the elements (soil, vegetation, and water) that make up the system. They unfold in the relief and results in the interaction of social actions originating the derived landscapes.

\subsubsection{Literature}

Data were collected from rainfall stations over 20 years at the Fundação Cearense de Meteorologia (Meteorology Foundation of Ceará, FUNCEME, (2020) in the municipalities of Aquiraz and adjacent areas, which is part of the behavioral analysis of the rainfall regime in the area. This stage seeks to understand the relief formation in the landscape at different times of the year according to the rainfall regime in Ceará.

Stations selected from the FUNCEME portal (2020) provided data for the analysis of the rainfall indexes. The selected ones, three in different cities, represent distinct areas related to the geomorphological unit in that place.

The first station is in the municipality of Guaramiranga (latitude $4^{\circ} 16^{\prime} 1.20$ "S and longitude $38^{\circ} 55^{\prime} 59.90$ "W), the second one in Horizonte (latitude $4^{\circ} 5^{\prime} 60.00$ "S and longitude 38 $28^{\prime} 59.90$ "W), and the third one in Aquiraz. Each one portrayed a geomorphological unit - the humid residual massif in Serra de Baturité, the pediplain, and the coastal zone. The yearly, monthly, and daily data were between 1974 and 2019.

\subsubsection{Cartographic Material and Georeferenced Bases}

Not only cartographic data collected from reliable sources, such as public agencies, (3) (4) (5), contributed to this research, but also manuscripts found in various libraries. The maps were the Multimodal Map of the State of Ceará, scale 1:900,000, 2013, DENIT; Map of the Geoenvironmental Compartimentalization Macroregion of Planning, scale 1:6,000,000, (3); Simplified Geological Map of Ceará, scale 1:600,000(4) 2015; Map of the Phytoecological Units of Ceará, scale 1:600,000, FUNCEME, 2007; Map of Climatic Types of Ceará, scale 1:600,000 (FUNCEME, 2020), (COGEERH, 2016).

Cartographic material, georeferenced data, geographic information system (GIS), and geoprocessing data software assisted in the production of maps that show the Pacoti River dynamics in its mouth. Geostatistical methods, such as interpolation of data by kriging or IDW (Inverse Distance Weighted), also aided the production.

Geoprocessing software (Di Biase, 1993) also contributed to the production of slope maps, classifying the landscape relief based on the results found in percentages after digital processing of the data, as seen in Table 1.

Table 1. Relationship between the slope types and relief

\begin{tabular}{cc}
\hline Slope type (\%) & Relief \\
\hline $0-3$ & Floodplain \\
$3-6$ & Plain to gently undulating \\
$6-12$ & Gently undulating to undulating \\
$12-20$ & Undulating to heavily undulating \\
$20-40$ & Heavily undulating to mountainous \\
$>40$ & Mountainous \\
\hline
\end{tabular}

Source: made by the authors (2020). 
The orbital images from the TM LANDSAT 8 satellite supported the extraction of information regarding the topic. The composition used was band 543 in the RGB (RED, GREEN, BLUE) spectrum in digital format. The image processing happened through MAPGEO 1.0, Spring 5.5.2, and QGIS 3.0.3. Functions related to the classification and treatment of images aimed at extracting spatial information relating to vegetation, land use, hydrography, road network, and urban areas (INPE, 2020).

Through ArcGIS 10.2, the maps had a 1:100,000 scale. With geoprocessing techniques, the developed research models assisted the detection, identification, qualification, and cartographic quantification. The use and occupation of the land underwent monitoring along with the analysis of the environmental impacts. The data and information from the surface and the phenomena and processes involved followed according to methodology (Cavalcante, 1997).

The methodology proposed by Lima (2004) aided the interpretation of the orbital images. The connection between visualized elements and the environmental characteristics took place by using interpretation criteria in orbital images through the texture, color, shape, size, volume, and location.

The interpretation was through the image segmentation function in SPRING 5.5.5, a Brazilian software for a geographic information system that had its origin in the Instituto Nacional de Pesquisas Espaciais (National Institute for Space Research, INPE). The segmentation consists of the identification and delimitation of the areas identified in the image (INPE, 2020).

\section{Result and Discussion}

The Pacoti River Watershed has a different characteristic from most of the predominant part of the state of Ceará, which concentrates vast regions of pediplain.

One can identify three distinct geomorphological units in the study area. One is the upriver in the Residual Massif in the Baturite Mountain, whose source is in Guaramiranga. The second unit is the outback surface in the middle course in Acarape, Guaiúba, and Itaitinga. At last, the coastal zone in the lower part of Pacoti River in Aquiraz and Eusébio.

Studies, analysis of georeferenced databases from government agencies, and fieldwork show a different physical characterization in the Pacoti River Watershed coastal zone. Thus, one can identify the climate condition, geological diversity, geomorphology, soil, vegetation, land use and occupation, and conservation units.

\subsection{Climate}

The Pacoti River Watershed region presents three types of climate. The sub-humid tropical warm comprises 50\% of the area in the middle and lower courses, in the compartmentalization of the outback surface and pre-coastal tablelands. The second is the humid tropical warm, being $40 \%$ of the region in the upper and middle courses, according to Figure 5. The humid tropical sub-warm covers $10 \%$ in the upper course in the Baturité Mountains.

The climate data of the Baturité Massif indicates that it is a humid enclave in the middle of the Semi-Arid Northeastern region. As in other humid highlands, it has a cold altitude mesoclimate. The rainfall level during an average year revealed the presence of a mono-modal rainfall regime, with a single rainy season peak in March and April (Bétard et al, 2008).

Climatic factors related to geological aspects influence the distribution of the surface drainage, notably in high regions. Since the rainfall levels are higher in mountainous areas, it causes the drainage network to act uniformly over the year and independent of the rainy season in Ceará, which is irregular.

In a valley system, water flows and drains through streams, creeks, rivers, lakes, and ponds. It runs until lower parts, which may be lakes, seas, oceans, inland seas in desert regions (Wingw, et al., 2001).

According to Ross (2012), reliefs are dynamic and manifest over time and space in various forms because of multiple interferences caused by geographical components.

From the data collected by the rainfall index stations in Guaramiranga, Horizonte, and Aquiraz, thus representing the different geomorphological compartments of the study area, it was possible to analyze the rainfall levels between the years 2000 and 2019 (FUNCEME, 2020) in the Humid Residual Massif, according to Figure 3. 


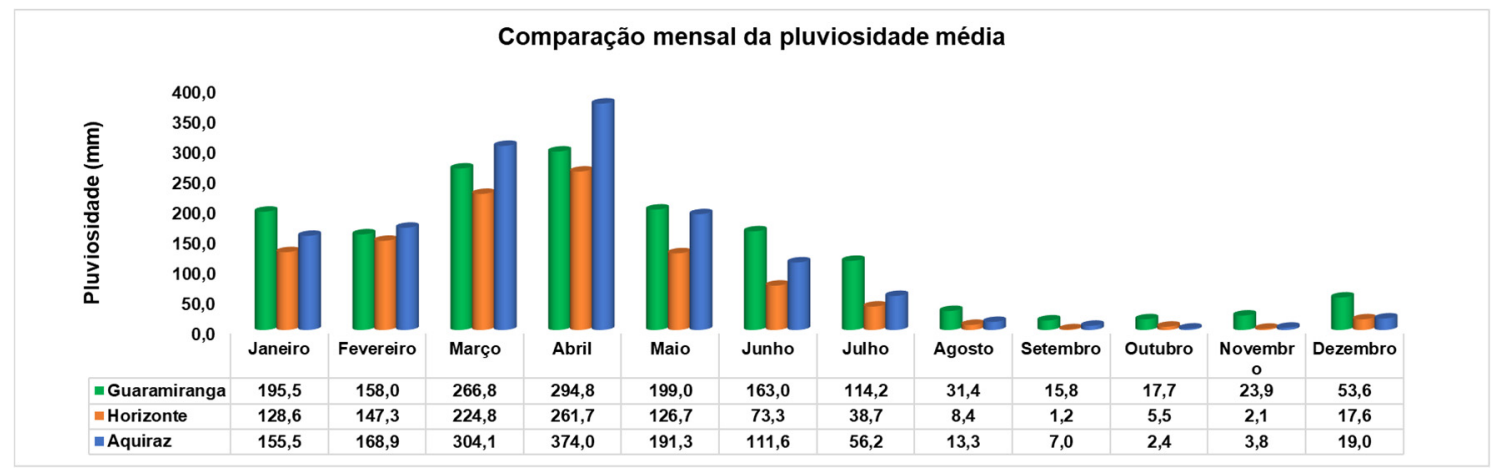

Figure 3. Monthly comparison of rainfall levels in the study area

Source: adaptation from FUNCEME data (2000 to 2019) (3).

In the Baturité Massif, the average rainfall level is high because of the altitude, which can reach more than a thousand meters above sea level, as shown in Figure 4.

The air mass going from the coastal zone to the continent meets a difference in pressure due to the altitude, thus provoking a rainfall volume higher than in other parts of the state.

2002, 2003, and 2009 (FUNCEME, 2020) had the highest rainfall levels for this 20 -year historical period. On the other hand, 2010 and 2012 (FUNCEME, 2020) had the lowest averages.

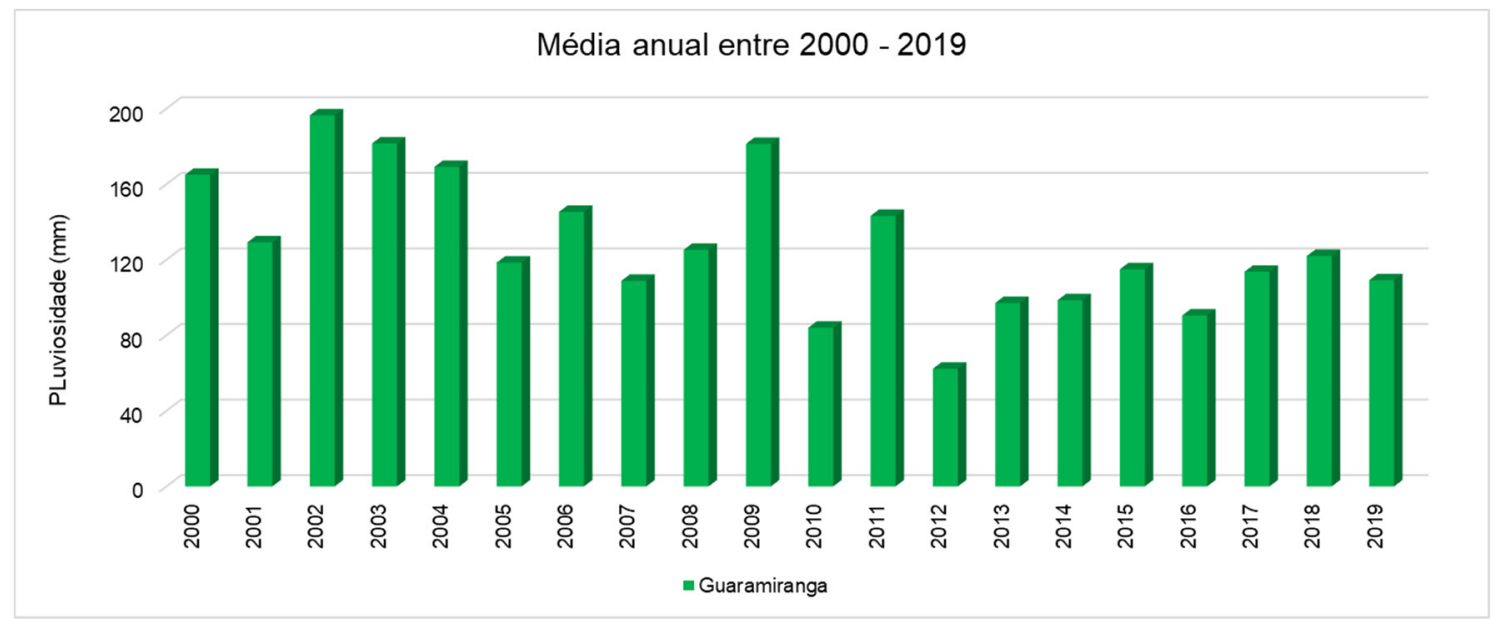

Figure 4. Yearly rainfall levels in Guaramiranga

Source: adaptation from FUNCEME data (3).

In Figure 5, it is possible to make a monthly analysis regarding the rainfall averages distributed throughout the year. The rainy season in the state of Ceara is in the first half of the year, more precisely in the first four months.

The figure below proves that the highest averages over the year are in March, April, and May, whose values are higher than the other months. 


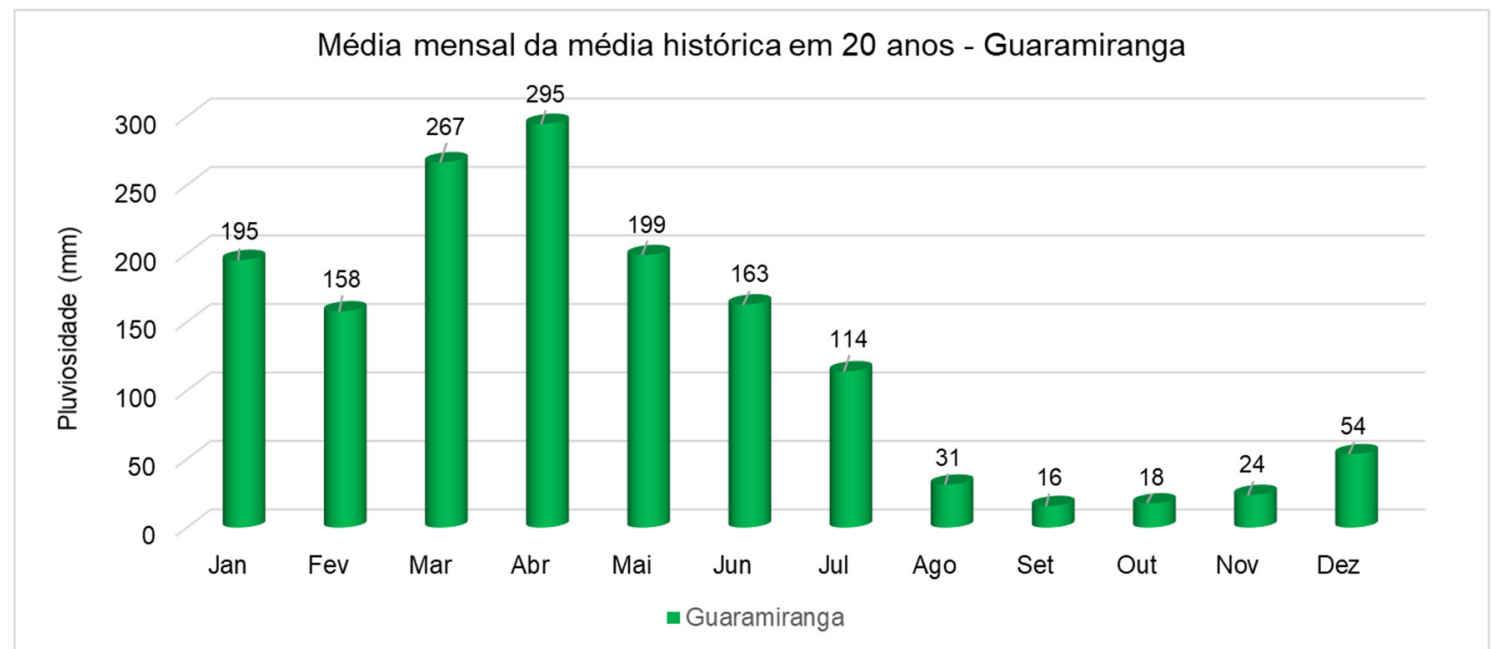

Figure 5. Monthly rainfall average in Guaramiranga

Source: adaptation from FUNCEME data (3)

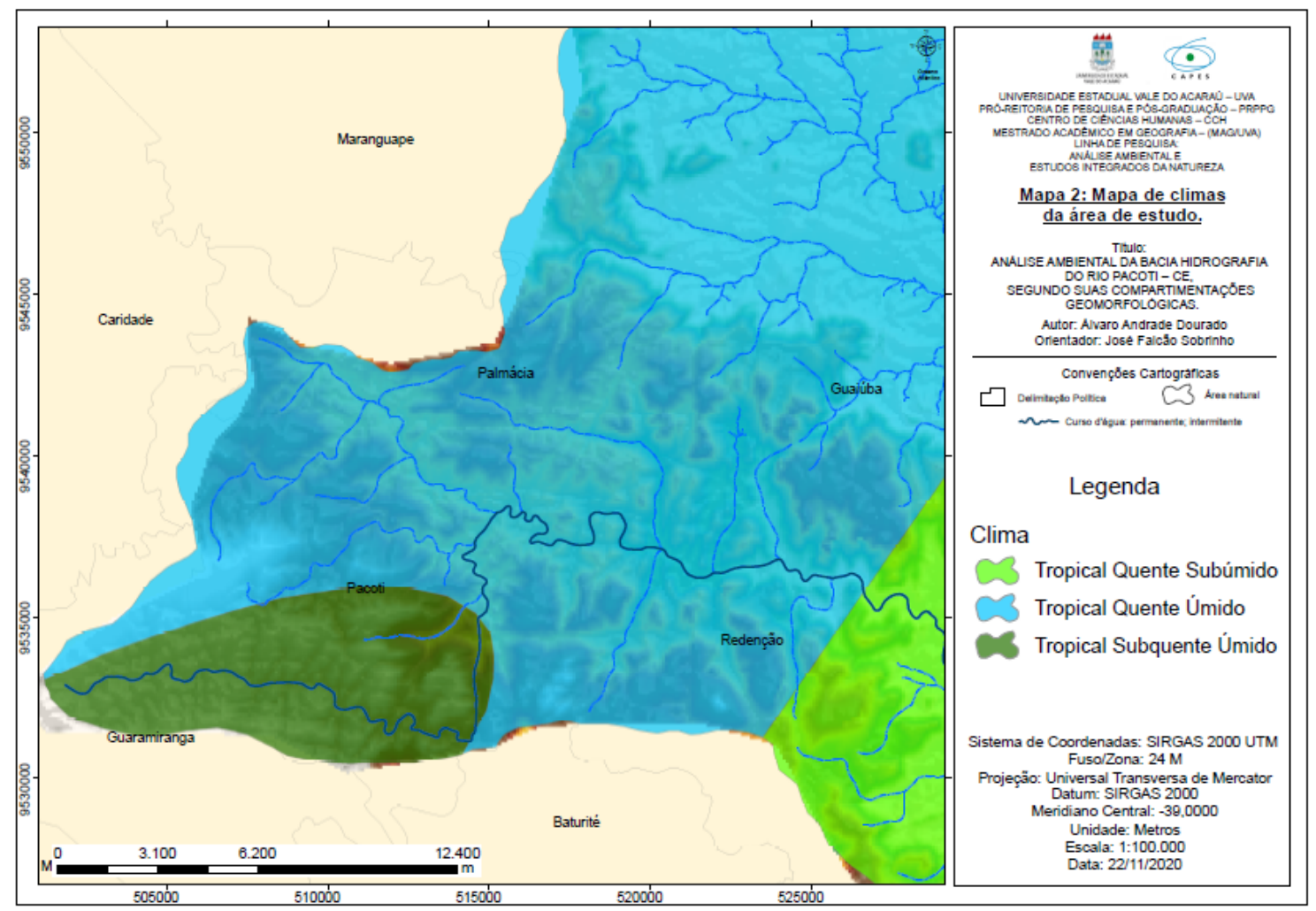

Figure 6. Climate map of the Residual Massif

Source: made by the authors (2020).

\subsection{Geology}

In drainage patterns, there are variations in different regions concerning the organization, density - shallow or dense - and shape, which may be dendritic, parallel, rectangular, radial.

When mapping the surface drainage system, one can see the similarity with branches of a tree, getting thicker and flowing as moving down from streams and rivers to the sea. However, the density and shape vary depending on the region according to the drainage patterns that allow the interpretation of the local geology and climate. (Wingw, et al., 2001) 
Even though there are several drainage patterns, most of them are directly linked to the local geology and can form dendritic, lattice, parallel, rectangular, radial, and ring patterns.

It is possible to identify geologically that the Pacoti River Watershed in the Residual Massif has a diverse geology. The nine types of geological events are the Barriers Formation, Holocene Alluvial Deposits, Holocene Coastal Aeolian Deposits, Holocene Coastal Deposits, Holocene Swamp and Mangrove Deposits, Tamboril-Santa Quitéria Formation, and Canindé and Independencia Units.

The Tamboril-Santa Quitéria and Independence Units prevail in the region of the Baturite Massif (Figure 7). One can see that the Tamboril-Santa Quitéria Unit covers almost the entire area, mainly in the higher altitudes, and the Independence Unit is in the lower parts at the foot of the massif.

The Red-Yellow Podzolic soils, Solonchak, Quartzose Marine Sand, Quartzose Dystrophic Sand, Brown Solonetz Solodized Non-Calcic, and Eutrophic Red-Yellow Podzol presented according to EMBRAPA (2019) are classified in three types of lithology, which are the Arche-Proterozoic Embasement, Proterozoic Embasement, and Cenozoic Sediments.

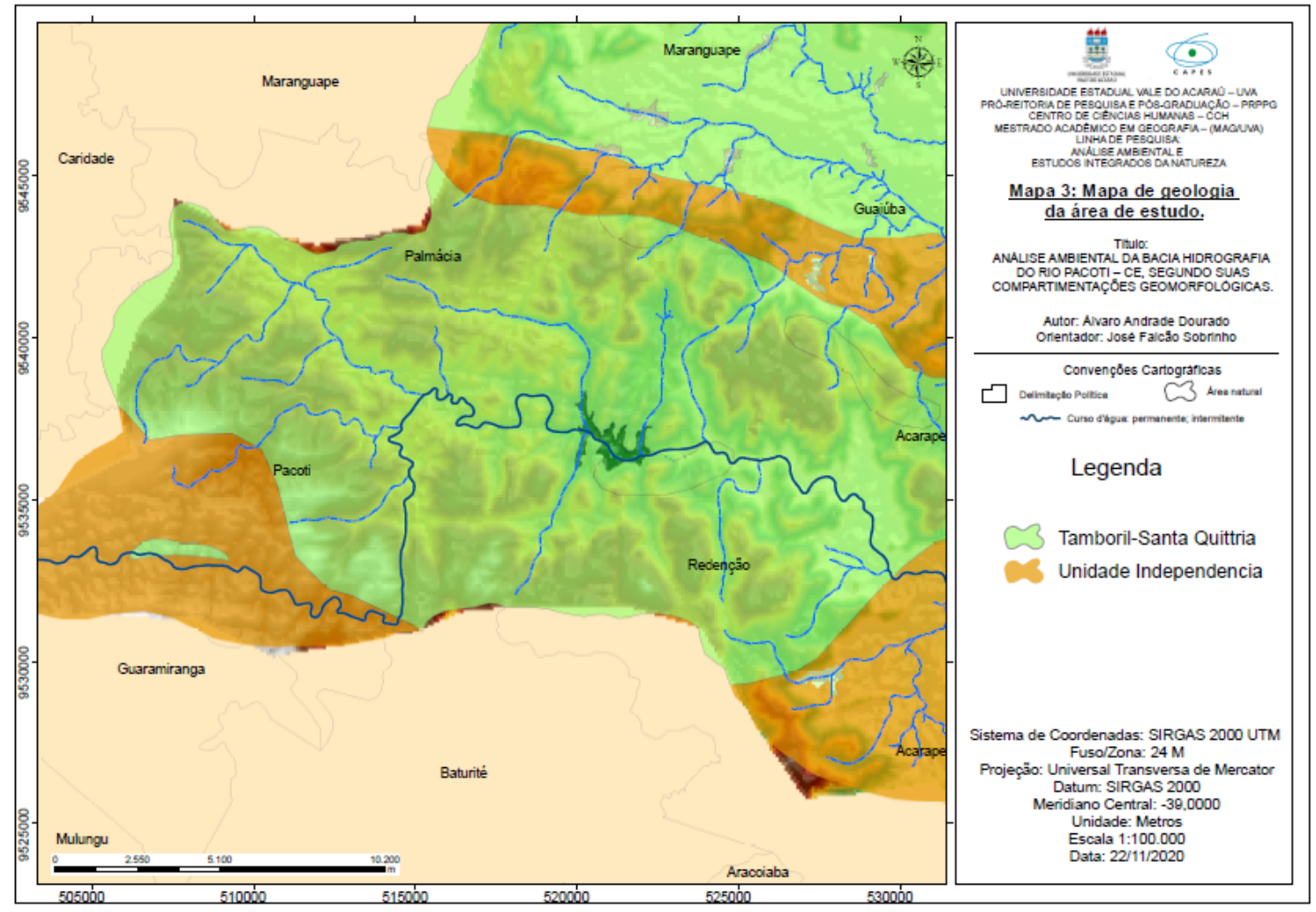

Figure 7. Geological map of the Residual Massif

Source: made by the authors (2020).

\subsection{Geomorphology}

The methodology used for the analyses was the proposition made by Ab'Saber, which establishes the treatment levels for geomorphological research, namely the compartments, surface structure, and physiology of the landscape (Ross, 2012).

The Residual Massif belongs to a Pre-Cambrian basement region - the Borborema Province - of the Cretaceous geological age with rocks formed from the Brasiliana Orogeny. The Baturité Massif is a rift shoulder, a transforming passive margin formed after the opening of the Equatorial Atlantic Ocean. (Bétard et al., 2008)

In the Baturite Massif, the prevailing super-crustal rocks of the Ceará Complex are gneiss with amphibolite facies of Paleoproterozoic age, remobilized migmatite, and intercalated with different minor outcrops of quartzite, mica schists, marbles, and leucogranite intrusions (regrouping the Canindé and Independência Units, (CPRM, 2003). In the eastern part, the basement has a partial cover of Cenozoic detrital sediments, not very thick, that characterize 
the Barrier Formation over the whole Ceará coastal zone, (Bétard et al., 2008).

In the same geomorphologic unit, the reliefs are usually called mountain seas and sugarloaf, found in the humid and sub-humid zones. The formation process is because of physical and chemical weathering, through the winds that erode the summit and the water that runs superficially over the rock deteriorating and rotting it, which gives it a rounded shape.

The Baturité Massif, which has $800 \mathrm{~km}^{2}$, represents a mountainous relief of moderate altitude (800-900 meters between its center and summit), distinguished by steep and sinuous slopes concerning the outback flattened surface, which ranges between $100 \mathrm{~m}$ and $200 \mathrm{~m}$. The geomorphological recognition carried out during the fieldwork and results of detailed morpho-structural cartography (Bétard et al., 2005b) have demonstrated the decisive role of erosion in the current configuration of the massif, not considering the neotectonics contributions (Peulvast, et al., 2006)

The Baturité Massif contours are similar to an immense residual resistant relief, or inselberg, preserved above a low composite pediplain - the outback surface. The surface corresponds to a large cyclic erosional notch in which there are numerous diverticula carved into the flank of the shoulders of rifts, horsts, and other bascule blocks outcropped during continental rifting and Cretaceous oceanic opening. This inheritance of the Cretaceous rifting gave to the regional landscape this type of residual relief $(1.115 \mathrm{~m}$ in Pico Alto), a natural obstacle concerning the humidity-laden trade winds coming from the Atlantic (Peulvast, et al., 2006)

The contour modeling is typical of a low crystalline pediplain, dissected and presenting residual reliefs with steep slopes of the inselberg. The literature describes pediplain between 100 and 200 meters in the surroundings of the Baturite Massif, with a mild slope (slope $<0.2 \%$ ) towards the ocean in the North and dissected from 10 to 20 meters only by an intermittent hydrographic network (Bétard et al., 2008)

The low sedimentary plateaus, or tablelands, form a slightly dissected accumulation around the Baturité Massif. On the topographic extension of the outback pediplain, this part is composed of Cenozoic detrital sediments of the Barrier Formation and characterized by the semi-arid climate. The cashew plantation, owned by large landowners (10), substitutes the caatinga vegetation.

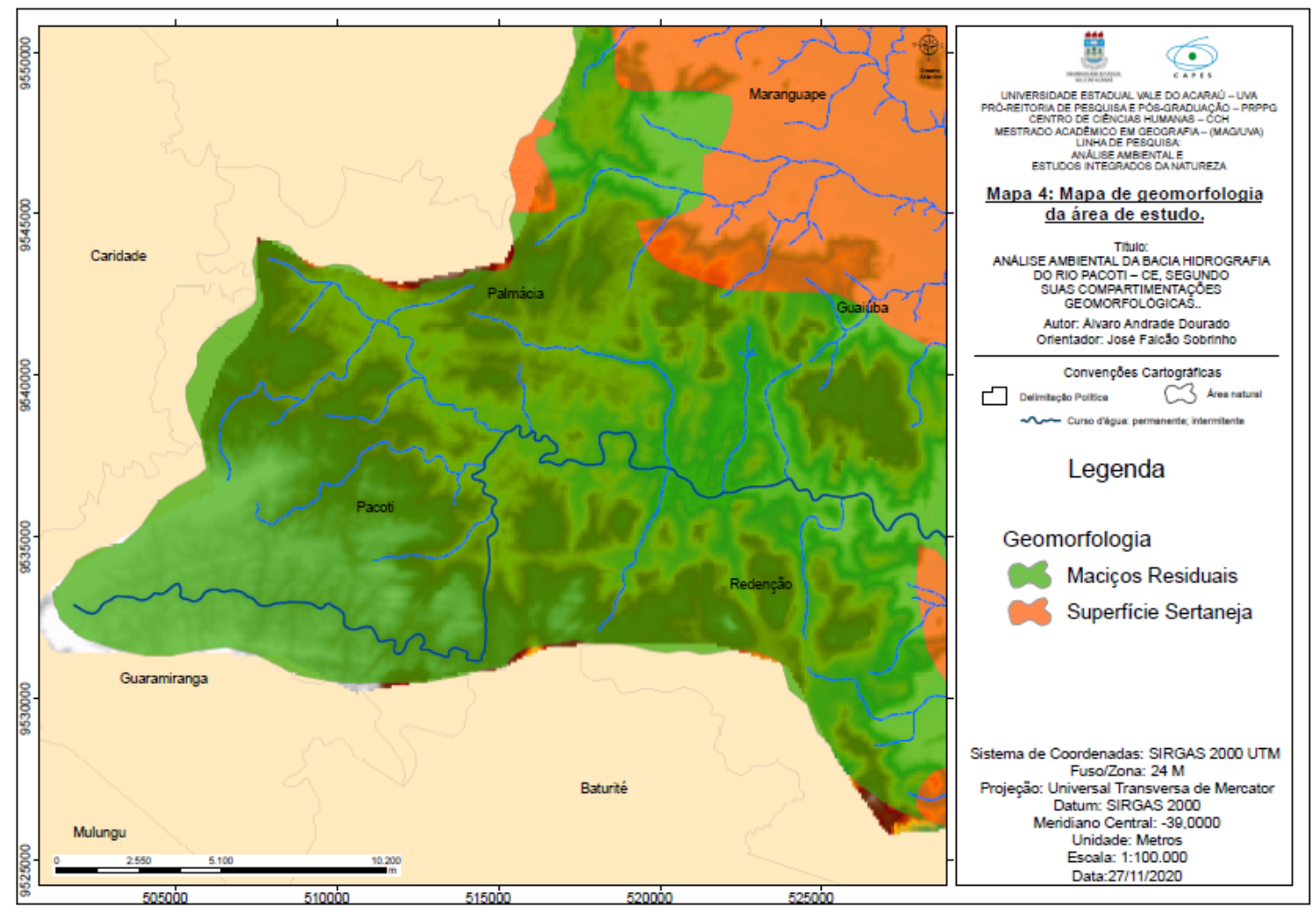

Figure 8. Geomorphology map of the Residual Massif

Source: made by the authors (2020). 


\subsection{Soils}

According to the EMBRAPA database (EMBRAPA, 2019), there are five different soil types in the studied area, which are the Red-Yellow Acrisol [Dystrophic PVA + Ortic RQ]; Red-Yellow Acrisol [Eutrophic PVA + Eutrophic RL]; Red-Yellow Acrisol [Eutrophic PVA + Ortic TC + Eutrophic RL]; Chromic Luvisol [Ortical TC + Eutrophic RL + Eutrophic SX]; Haplic Planosol [Eutrophic SX + Eutrophic PVA].

Acrisol has higher clay content in the sub-surface horizons concerning the surface horizons, which characterizes a textural gradient over the profile. The color can vary from grayish to reddish, with yellow and red hues being the most common (EMBRAPA, 2019).

The predominant minerals are low activity clays (kaolinite) and oxides, which contribute to the cation exchange capacity value below $27 \mathrm{cmolc} \mathrm{kg}-1$, and it is also possible to present alite character (EMBRAPA, 2019).

Luvisol is composed of mineral material, presenting a textural B horizon with the clay of high activity and base saturation in the first $100 \mathrm{~cm}$ of the B horizon (even the BA horizon), below the A horizon types (except chernozemic A), and under E horizon. It has plinthic, vertic, and planic horizons, on the condition that there is no Plinthosol, Vertisol, and Planosol, since they do not match the textural B horizon surface (EMBRAPA, 2019).

Planosol has a sandy texture at the surface, an increase in clay in the sub-surface, and abrupt textural change with a textural gradient. It is dense in the sub-surface and extremely hard when dry, and often with a prismatic or columnar structure. The low permeability in the sub-surface conditions the cycles of iron reduction and oxidation, causing it to be gray or variegated and mottling. In general, a light-colored eluvial horizon overlies the sub-surface horizon (EMBRAPA, 2019)

According to the authors (Bétard et al., 2008), the pedogenesis in the Baturité Massif is predominantly primary, that is, without clear evidence of evolutionary heritages.

According to Figure 9, the most predominant soils in the massif are the Red-Yellow Acrisol [PVA Dystrophic + RQ Orthic] and the Haplic Planosol [SX Eutrophic + PVA Eutrophic]. The Red-Yellow Acrisol is present in almost all of the massif, while the Haplic Planosol is discretely present in the massif and is found mainly at the foot of the windward ridge.

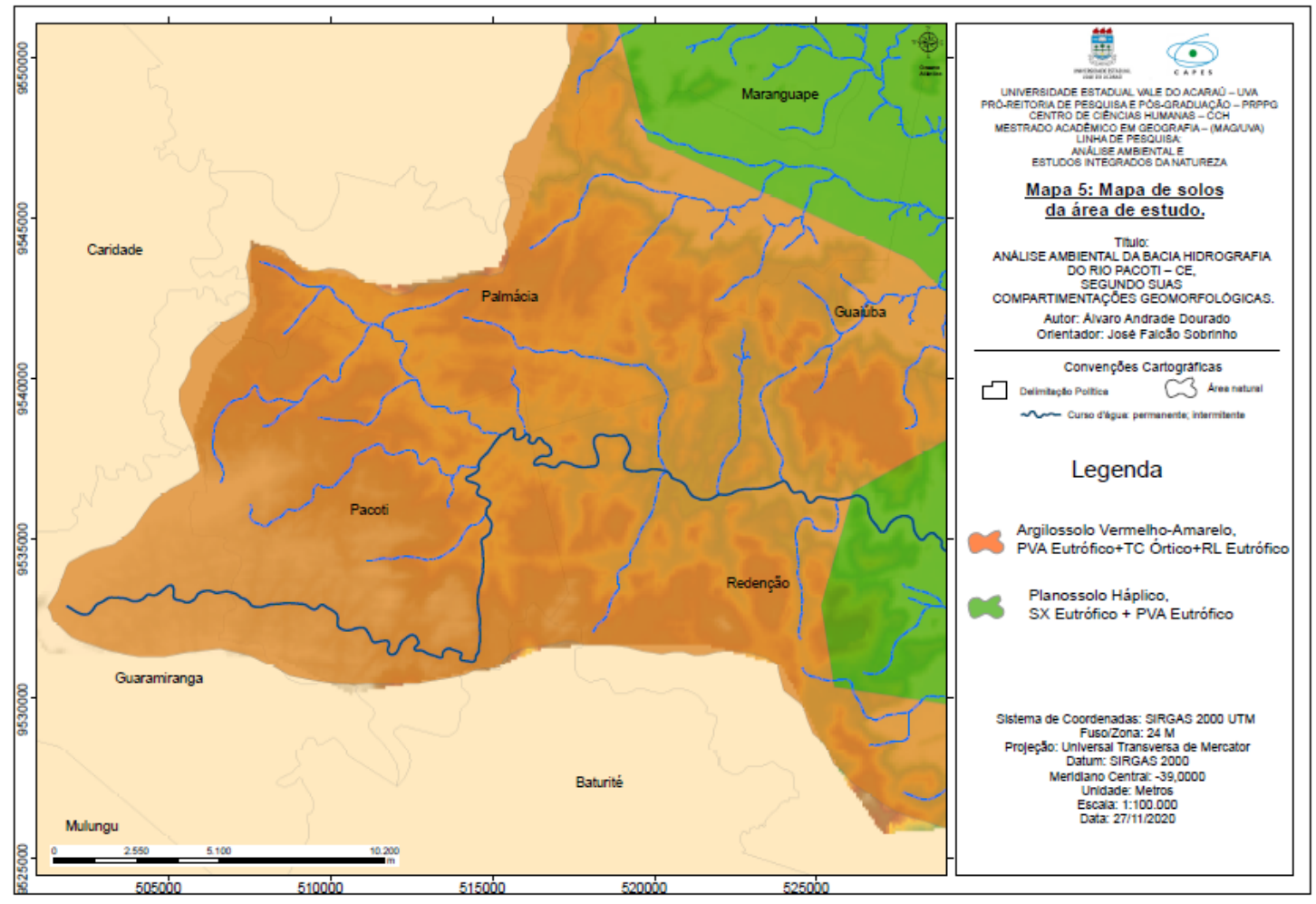

Figure 9. Soil map of the Residual Massif

Source: made by the authors (2020) 


\subsection{Vegetation}

Figure 10 reveals the three vegetation types found in the Baturite Massif, namely the Crystalline Caatinga, Crystalline Seasonal Tropical Forest, and Crystalline Rainforest. The first one is not present at high altitudes in the massif, but only at the foot.

The Crystalline Rainforest is present in the higher parts of the massif where temperatures are milder and favor the development of taller and more voluminous species.

The vegetation types are decisive for the rainfall differences in the Baturite Massif since the eastern windward slope has the rainforest vegetation, medium to high, receiving the influence of the trade winds coming from the East. The western leeward slope presents the caatinga from the seasonal tropical forest, which reaches up to 800 meters of altitude on average.

It is essential the continuity of the forests in the Baturite Massif in its two slopes, going from a perennial forest, which creates a rainforest island on the massif top, and the semi-arid xerophytic caatinga invading the outback surface through a transition belt of the seasonal tropical forest (Figueiredo, 1997)

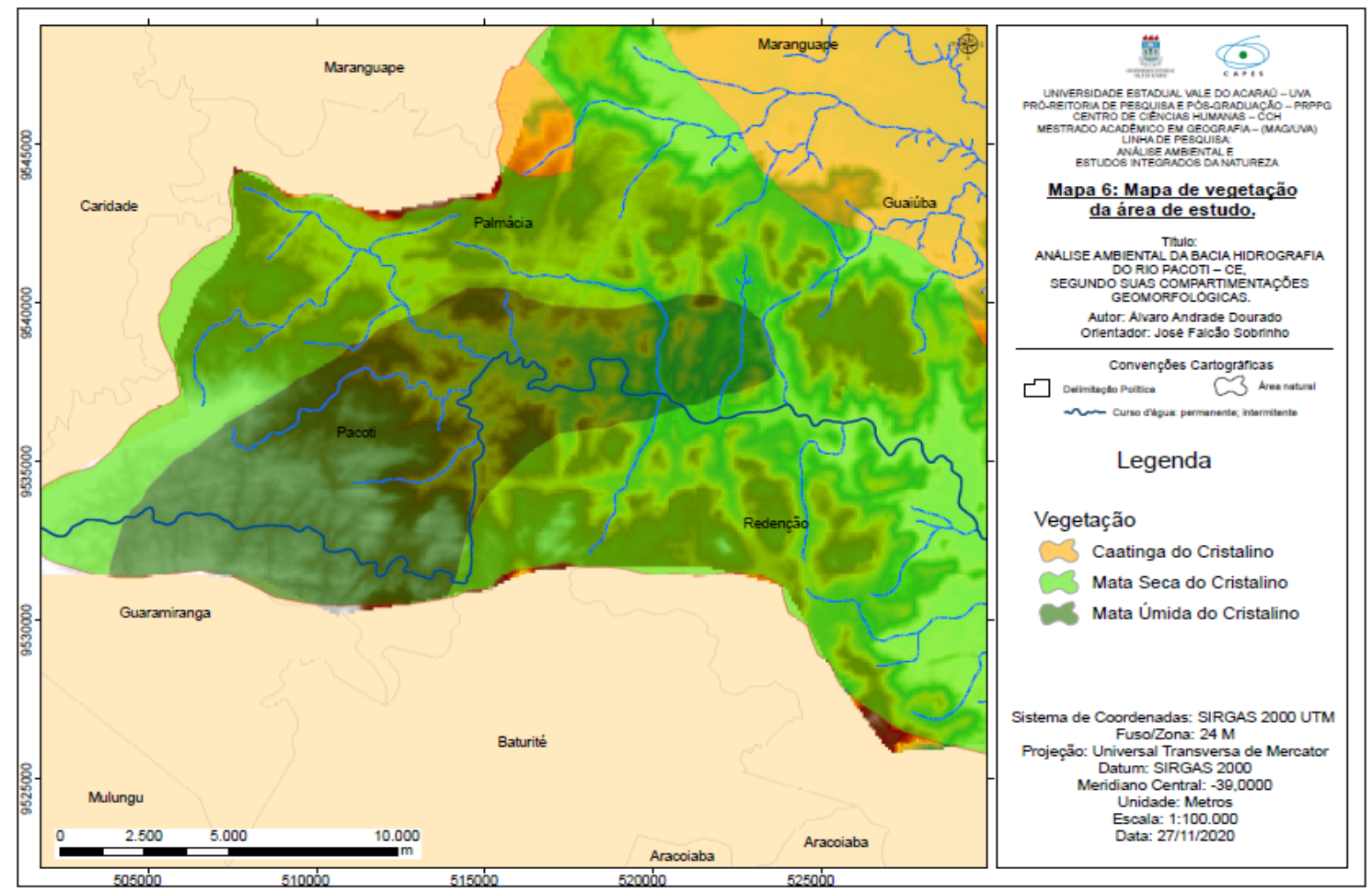

Figure 10. Vegetation map of the Residual Massif

Source: made by the authors (2020).

\subsection{Use and Occupation of the Land}

The land use and occupation are according to the arrangement of soil types, as they are intrinsically related. It is used mainly for agricultural purposes. Yearly, temporary, and permanent agriculture is usual in the watershed (Figure 11). Horticulture usually takes place in the Baturite and Aratanha Mountains because of the climatic and soil conditions.

The concept of urban land can be understood as the rebound of social reproduction in the urban space plan, while the land occupation is how the building can occupy urban land, depending on the urban indexes that apply to it (Takeda, 2013)

The concept of ownership of natural resources is significant for their preservation. The understanding of nature as a public good in which humans are an essential part constitutes an indispensable step to overcome predatory actions on the environment and themselves (SEMACE, 2019). 


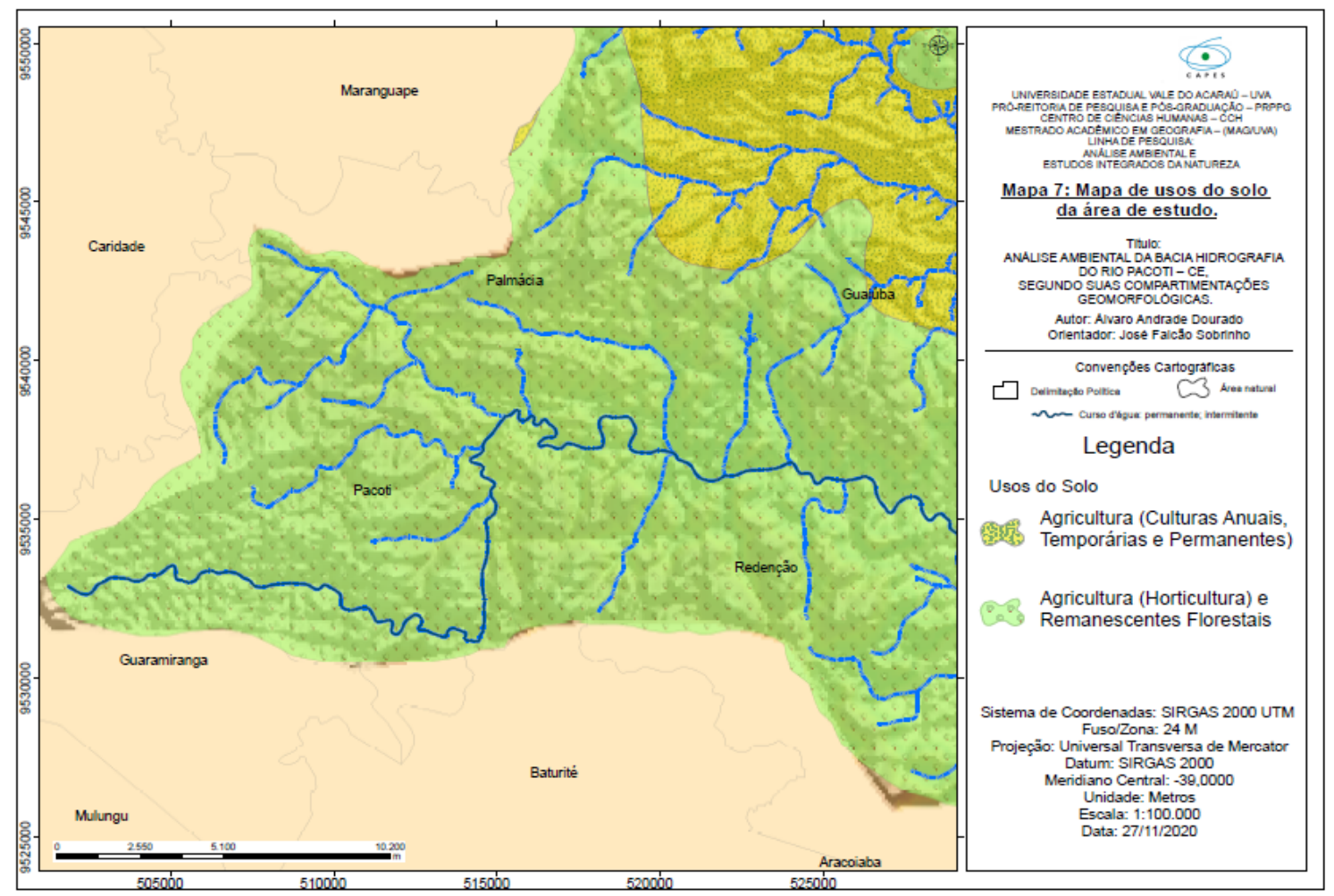

Figure 11. Use and occupation of land in the Residual Massif

Source: made by the authors (2020).

\subsection{Conservation Units}

In the watershed region, the three conservation units (Figure 12) inside the Environmental Protection Areas (EPA) are the Pacoti River, located in the lower course at its mouth, Aratanha Mountain, and Baturité Mountain.

A data survey about the conservation units enhanced the information about these preservation areas. The collected data had origin in the website from the Environmental State Superintendence (SEMACE, 2019), a governamental agency.

The main problems in the APA are the result of human action caused by real estate speculation with the construction of summer houses, gated communities, and hotel developments, disposal of solid waste on the banks of the spring, occupation by residences in the area of permanent preservation of the river, and vehicle traffic on the dunes.

The Baturité Mountain EPA is the first and most extensive one created by the Ceara State Government and established through the State Decree No 20.956, on September 18, 1990, changed by Decree No 27.290, on December 15, 2003. It has 32,690 hectares in the Northeastern Ceará, in the Baturité mountainous region. Bounded by the quota 600 (six hundred) meters, it is composed of the municipalities of Aratuba, Baturité, Capistrano, Guaramiranga, Mulungu, Pacoti, Caridade, and Redenção. Being $90 \mathrm{~km}$ far from Fortaleza, the accesses are the CE-060 highway, Fortaleza-Baturité, or the CE-065 highway, Fortaleza-Palmácia (SEMACE, 2019).

The Baturité Mountain EPA has a complex vegetational cover because of its unique climatic characteristics. Therefore, it serves as an ecological refuge for a diversified fauna and flora, being an indispensable condition for watershed formation and maintenance. The importance is unquestionable both for the region and for the supply of Fortaleza. 


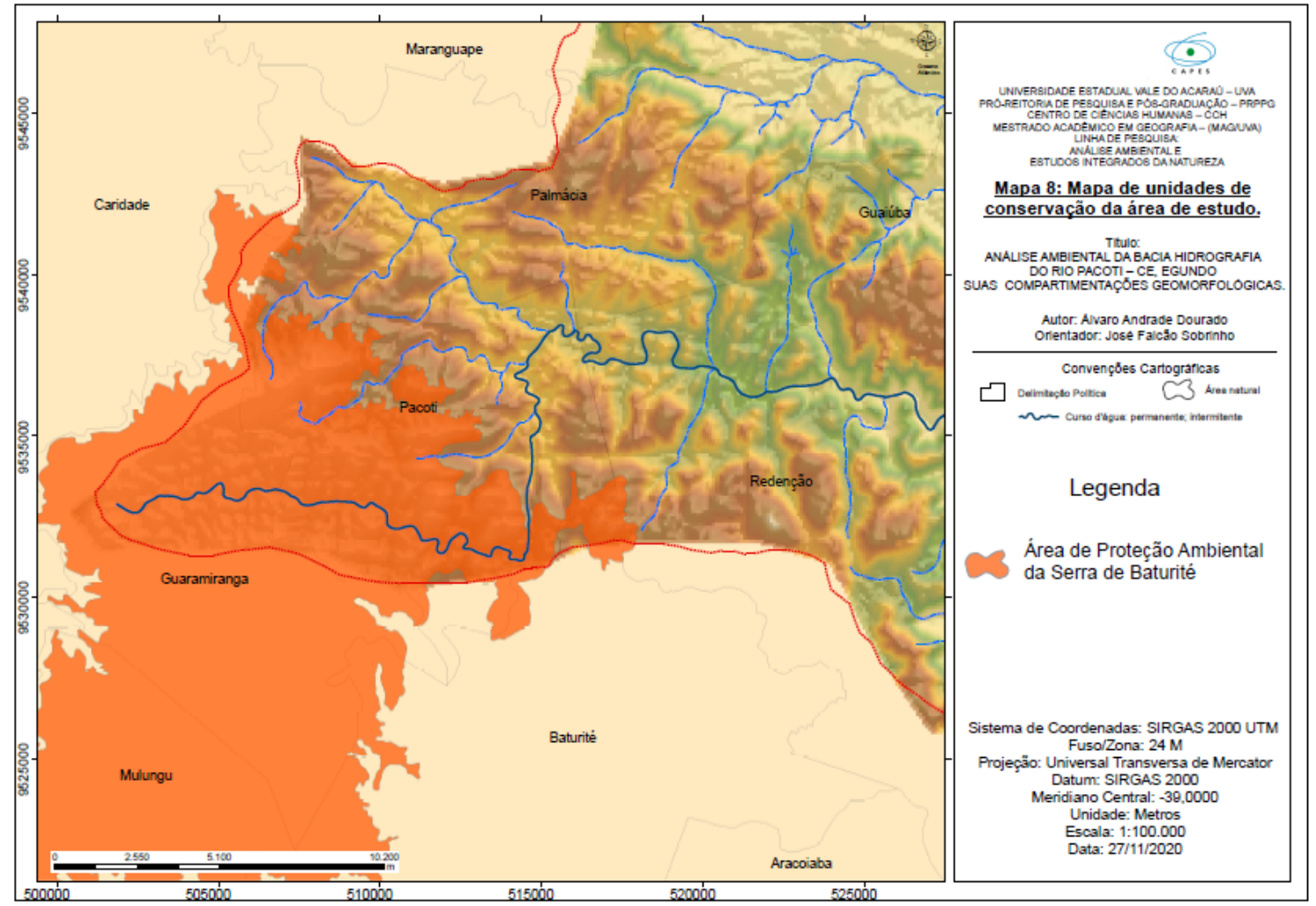

Figure 12. Conservation unit map of the Residual Massif

Source: made by the authors (2020)

EPAs are one of the most significant rainforest enclaves in Ceará, representing an exceptional environment in caatinga and the main drainage dispersion center of the Northwestern Ceará. Out of the three rivers with springs in the massif, the Pacoti River is the most important. On the eastern slope, the surface has as drainage the Aracoiaba River, which is part of the Choro Watershed. On the western slope, the drainage is the Siriema and Bom Jardim Creeks, and the Canindé Sub-Basin, which is part of the Curu Watershed.

In the Baturité Mountain EPA, the usual human activity has been agriculture. Despite the natural diversity and possibilities of other agricultural activities, it has focused on monocultures.

Coffee in the highland area and sugar cane in the alveolar plains are the cultures that shape the formation of the urban and labor nuclei. Considering its territorial extension, the historical aspects of colonization, and its eight municipalities, the Baturité Mountain EPA shelters communities with different origins and ethnicities, totaling a high population compared to other mountainous regions in Ceará.

The problems existing in Baturité Mountain EPA are the result of human activities, such as hunting and capturing of wild animals, deforestation and burning, use of pesticides, improper disposal of solid waste, water pollution, lack of basic sanitation, real estate speculation, mass tourism, inadequate agricultural model, and lack of sustainable income alternatives for the population.

\section{Final Considerations}

The digital image geoprocessing techniques used in the physical characterization of natural landscape units have been efficient, fast, and precise when identifying local characteristics.

The Geographic Information System (GIS) assisted the characterization process of the Baturite Massif, outback surface, and coastal zone in the Pacoti Watershed. Characterizing the climate, geology, geomorphology, soil, vegetation, land use and occupation, and conservation units constitute a significant step to evaluate environmental impacts potentially harmful to the local natural conditions.

Geoprocessing techniques applied on cartographic bases from public agencies generated maps that assisted the local physical characterization. Based on this, the Pacoti River upper course (Baturité Mountain) presents unique characteristics in its context, which requires an integrated analysis to understand the natural phenomena occurring 
in the region directly influenced by human action.

However, the use of geoprocessing techniques demonstrates a viable and appropriate alternative for the characterization and monitoring of areas of interest for preservation, which contribute to decisions about the conservation of natural conditions.

The suggestion here is that the environmental agencies use more geoprocessing techniques to monitor areas of interest, such as the coastal zone, to support decision-making. The reason is that they have proven to be a reliable alternative for this purpose.

\section{References}

Bétard, F., Peulvast, J.-P., \& Claudino-Sales, V. (2019). Caracterização morfopedólogica de uma serra úmida no semiárido do nordeste brasileiro: o caso do maciço de Baturité-CE (morphopedological characterization of a humid mountain in the brazilian semi-arid north-east). Mercator, Fortaleza, 6(12), 107-126. Retrieved from http://www.mercator.ufc.br/mercator/article/view/49

Cavalcante, A. P. B. et al. (1997). Desenvolvimento Sustentável e Planejamento. Bases Teóricas e Conceituais. Fortaleza UFC - Imprensa Universitária.

COGERH. Comitê de bacias hidrográficas do Ceará (Ceará). (2016). Agência Nacional de Águas - Ana. Comitê de Bacias. Retrieved from http://www.cbh.gov.br/DataGrid/GridCeara.aspx

CPRM. (2003). Atlas digital de geologia e recursos minerais do Ceará. Mapas na escala 1:500,000. Serviço Geológico do Brasil.

De Biasi, M. (1993). A carta clinográfica: os métodos de representação e sua confecção. Revista de Geografia, 6, 45-60. https://doi.org/10.7154/RDG.1992.0006.0004

Dourado, Á. A., Falcão Sobrinho, J., Barbosa, E., Francisca, E. L. B., \& Ernane, C. L. (2021). Mapping and Characterization of the Landscape Units of the Coastal Hydrographic Basin of Rio Pacoti, Ceará, Brazil. Journal of Geographic Information System, 13.

Dourado, A. A. (2021). Caracterização das unidades de paisagens naturais da bacia hidrográfica do rio Pacoti-CE. Dissertação de Mestrado. MAG/UVA.

EMBRAPA - Empresa Brasileira de Pesquisa Agropecuária. (2019). Solos Brasileiros. Brasília. Retrieved from https://www.embrapa.br/tema-solos-brasileiros/solos-do-brasil

Falcão Sobrinho, J. (2006). O relevo, elemento e âncora, na dinâmica da paisagem do vale, verde e cinza, do Acaraú, no estado do Ceará. 300 f. Tese (Doutorado) - Curso de Faculdade de Filosofia, Letras e Ciências Humanas, Departamento de Geografia, Universidade de São Paulo, São Paulo.

Falcão Sobrinho, J. (2020). A Natureza do Vale do Acaraú: um olhar atravpes das sinuosidades do relevo (1st ed.). Sobral: SertãoCult. v. 1. 196p. https://doi.org/10.35260/87429137-2020

Figueiredo, M. A. (1997). A cobertura vegetal do estado do Ceará (unidades fitoecológicas). Atlas do Ceará. IPLANCE, 65. 9.

Frota, P. V. (2006). Propostas para gestão integrada de recursos hídricos na bacia hidrográfica do Rio Jardim DF. 167 f. Dissertação (Mestrado) - Curso de Desenvolvimento Sustentável, Centro de Desenvolvimento Sustentável, Universidade de Brasília - Unb, Brasília - Df, 2006. Retrieved from https://core.ac.uk/download/pdf/33531754.pdf

FUNCEME. Fundação Cearense de Meteorologia e Recursos Hídricos. (2020). Postos Pluviométricos. Retrieved from http://www.funceme.br/produtos/script/chuvas/Download_de_series_historicas/DownloadChuvasPublico.ph $\mathrm{p}$

INPE. Centro Regional do Nordeste. Brasília. (2020). Retrieved from http://www.inpe.br/crn/

IPECE. Gerência de estatísticas, Geografia e informações. Fortaleza. (2020). Retrieved from https://www.ipece.ce.gov.br/estatistica-e-geografia/

Lima, E. C. (2004). ANÁLISE E MANEJO GEOAMBIENTAL DAS NASCENTES DO ALTO RIO ACARAÚ: SERRA $D A S$ MATAS - CE. 2004. 178 f. Dissertação (Mestrado) - Curso de Mestrado Acadêmico em Geografia, Departamento de Geografia, Universidade Estadual do Ceará, Fortaleza.

Peulvast, J. P., Claudino Sales, V., Bezerra, F. H., \& Bétard, F. (2006). Landforms and neotectonics in the equatorial passive margin of Brazil. Geodinâmica Acta, 19(1), 51-71. https://doi.org/10.3166/ga.19.51-71 
Ross, J. L. S. (2012). Geomorfologia, ambiente e planejamento (9th ed.). São Paulo: Editora Contexto, 89 p.

SEMACE - Superintendência Estadual do Meio Ambiente. Área de Proteção Ambiental da Serra de Baturité. Retrieved from https://www.semace.ce.gov.br/2010/12/08/apa-da-serra-de-baturite/

Superintendência Estadual Do Meio Ambiente - Semace. Área de Proteção Ambiental do Rio Pacoti. Retrieved from https://www.semace.ce.gov.br/2010/12/08/area-de-protecao-ambiental-do-rio-pacoti/

Takeda, T. de O. (2013). Uso e ocupação do solo urbano. 30 f. Dissertação (Mestrado) - Curso de Direito Imobiliário, Pontifícia Universidade Católica de Goiás, Goiás. Retrieved from https://www.jurisway.org.br/v2/dhall.asp?id_dh=12363

Winge, M. et. al. (2001). Glossário Geológico Ilustrado. Disponível na internet em 31 de maio de 2020 no site. Retrieved from http://sigep.cprm.gov.br/glossario/

\section{Copyrights}

Copyright for this article is retained by the author(s), with first publication rights granted to the journal.

This is an open-access article distributed under the terms and conditions of the Creative Commons Attribution license (http://creativecommons.org/licenses/by/4.0/). 